\title{
Selection of Shipping Container Vendors Using Analytical Hierarchy Process (AHP)
}

\author{
Muhammad Jumandono $^{1}$ and Moses Laksono Singgih ${ }^{1}$
}

\begin{abstract}
This research was conducted on a service company in Surabaya engaged in forwarder/ logistic using containers. Customers from this company spread in East Java, such as Surabaya, Sidoarjo, Gresik, and Mojokerto. The chosen export destination is exporting to the Middle East, such as Saudi Arabia and Qatar. The problem faced by the company is the selection of container vendors for shipping exports to the Middle East. There are 3 shipping container vendors that are often used for shipping to the Middle East, namely vendors A, $B$, dan $C$. This research uses the FGD method and Analytical Hierarchy Process (AHP) method. The FGD method is a method used to find answers to each problem through expert forums or discussion groups. This method will produce relevant criteria. This FGD method will be combined with the AHP method which has a good structure. This is evidenced by the matrices produced until a consistency test. AHP method can solve problems that have multi-criteria up to sub-criteria. Systematic criteria assessment with the first rank in a row until the last rank is the Quality (22.6\%), Cost (22.4\%), Time (18.3\%), Bankruptcy (7.6\%), Long-term Cooperation (6.9\%), Order Fulfillment (6.1\%), Company Profile (5.6\%), Standard and Environmental Certification (5.4\%), and Exploitation Contract (5.1\%). The chosen vendor is vendor $B$ has the highest priority (36.8\%), then followed by vendor $A$ is ranked second (33.9\%), and the last is vendor C (29.3\%).
\end{abstract}

Keywords-Vendor Selection, Criteria, FGD Method, AHP Method, and Alternatives/Choices.

\section{INTRODUCTION ${ }^{1}$}

The company that became an object is a service company engaged in forwarders/logistics in Surabaya. Transactions in the export sector use containers as a shipping mode. The problem faced by companies is the selection of container vendors for export shipments to the Middle East. There are 3 shipping container vendors that are often used for shipping, namely Vendors A, B, and C. These vendors have offices in Surabaya. When customers order services, the marketing division does not have the best recommendation vendor. Coordination between the marketing division with the customer requires time that is not important. If the marketing division has the best one vendor, then the company's business process will be faster.

Therefore it is necessary to hold research to make decisions about these problems. The method used is the method of Focus Group Discussion (FGD) and Analytical

\footnotetext{
${ }^{1}$ Muhammad Jumandono and Moses Laksono Singgih are with Department of Management Technology, Institut Teknologi Sepuluh Nopember, Indonesia. Email: moseslsinggih@ie.its.ac.id.
}

Hierarchy Process (AHP). The FGD method is a method that produces decisions from joint discussions to reach consensus. This method will produce relevant criteria. This FGD method will be combined with the AHP method which has a good structure, this is evidenced by the resulting matrices to consistency test. AHP method is a method that can change qualitative data into quantitative data using questionnaires as a data retrieval medium. The data will then be processed as decision making from alternatives/choices that exist with the criteria used.

\section{LITERATURE REVIEW}

\section{A. Focus Group Discussion(FGD)}

FGD is a method used to find answers to problems through expert forums or discussion groups. In the FGD, opinions from the experts involved must share opinions with the group. Some of the processes involved in the discussion are the presence of networks, knowledge, negotiations, relationship strengths, and learning processes [1]. Related experts or respondents are grouped into one group. This collection is done to improve the validity of the information that is the focus of the discussion [2]. The ideal indication of the FGD is that the severely involved experts control the information gathered and discussions that are conducive [3]. Analysis of the results of the FGD requires a considerable and often relative time. These results are usually "broad and innovative" [4].

\section{B. Analytical Hierarchy Process (AHP)}

The AHP method can solve complex problems by making hierarchies, those who are concerned (experts) provide an assessment based on considerations that make a variable a priority or not. This method can combines the power of logic and feel concerned in various problems, then synthesize considerations into suitable results as presented in the considerations that have been made [5].

AHP method is used to scale the ratio of both discrete and continuous pairing comparisons. These considerations can be taken from the actual size or from the scale that reflects the strength of relative feelings and preferences. Special attention to the AHP method lies in deviations from consistency. This AHP method is often found in decision making with many criteria, prediction/planning, determining priorities of strategies, and allocation of resources. The AHP method helps translate rational and irrational intuition into uncertainties in complex settings[6]. 


\section{1) Principles of Hierarchy Preparation}

The principles of arranging hierarchy are hierarchical description and problem solving, by becoming separate elements in solving problems, this is realized through more detailed knowledge of complex thoughts in the main elements. The lower hierarchy description intends to obtain measurable criteria [7].

\section{2) Principles of Decision Assessment}

Assessment is done by comparing the elements below to the elements above, for example, is the assessment of criteria for the objectives achieved and the assessment of alternatives to the criteria formulated [5].

The paired assessment carried out is guided by prioritizing elements with pairwise comparisons. The following are provisions that are guidelines [5].

\section{3) Principles of Logic Consistency}

To get the CR value, a systematic calculation is performed. Following are the steps to calculate the CR value [5]:
1. Looking for eigenvalue vector or relative weight, by multiplying the results of the sum of weights with the average weight produced.

2. Looking for the matrix value ( $\lambda$ maks), this value is the average value of the eigenvector previously obtained.

3. Calculate the value of the Consistency Index (CI) for each matrix $\mathrm{n}$ using the formula:

$$
\mathrm{CI}=\left(\lambda_{\text {maks }}-\mathrm{n}\right) /(\mathrm{n}-1)
$$

4. Calculating the value of Consistency Ratio (CR) with the formula:

$$
\mathrm{CR}=\mathrm{CI} / \mathrm{RI}
$$

Where RI is the value of the Random Index matrix. This value can be obtained from Table 2 value of Random Index(RI).

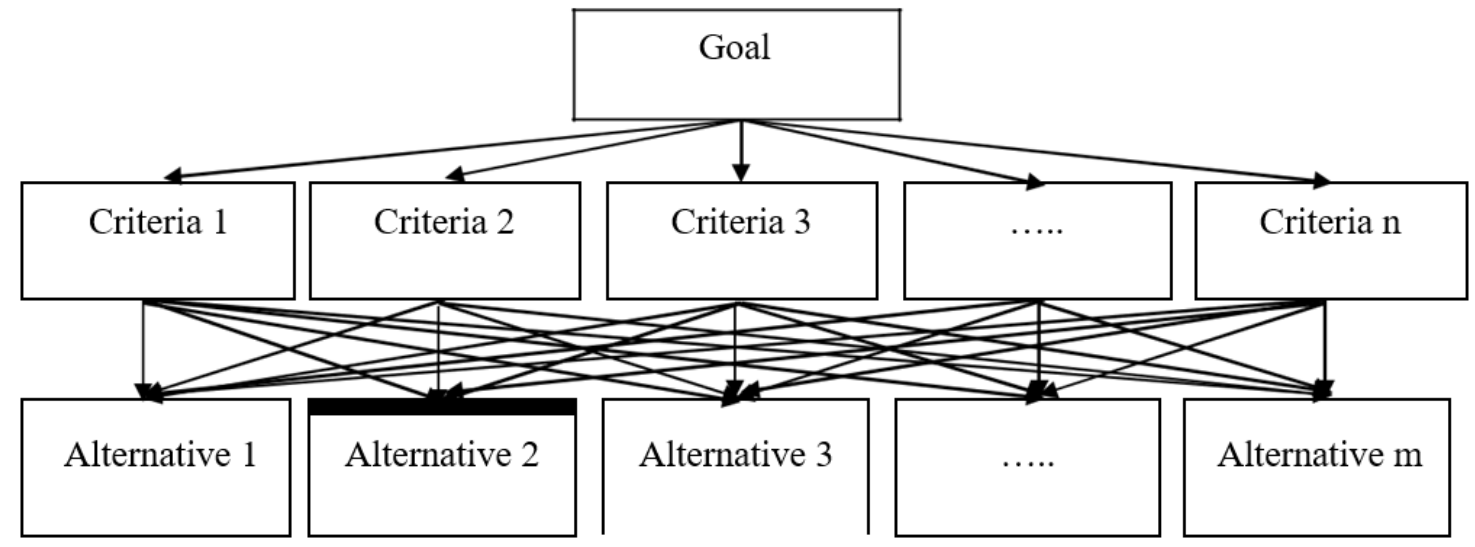

Figure 1. Hierarchy Illustration

TABLE 1.

\begin{tabular}{|c|c|c|}
\hline Interest level & Definition & Explanation \\
\hline 1 & Both elements are equally important. & The contribution of the two elements is as large as the goal. \\
\hline 3 & One element is slightly more important than other elements & $\begin{array}{l}\text { Experience and assessment are a bit more supportive of one } \\
\text { element than others }\end{array}$ \\
\hline 5 & One element is slightly more important than other elements & $\begin{array}{l}\text { Experience and assessment strongly support one element } \\
\text { compared to another. }\end{array}$ \\
\hline 7 & One element is very important compared to other elements & One element is very dominant compared to other elements \\
\hline 9 & $\begin{array}{l}\text { One element is absolutely important compared to other } \\
\text { elements }\end{array}$ & $\begin{array}{l}\text { One element proved to be very high in importance compared to } \\
\text { other elements. }\end{array}$ \\
\hline $2,4,6,8$ & Values between two considerations are close together & Compromise value between $1,3,5,7,9$ \\
\hline Reciprocal & $\mathrm{aji}=1 / \mathrm{aij}$ & $\begin{array}{l}\text { If element } i \text { has one number above when compared toelement } j \text {, } \\
\text { then } j \text { has the opposite value when compared to element } i \text {. }\end{array}$ \\
\hline
\end{tabular}

PRIORITIZING ELEMENTS WITH PAIRWISE COMPARISONS

TABLE 2.

VALUE OF RANDOM INDEX (RI)

\begin{tabular}{ccccccccccc}
\hline \hline Sequence of Matrices & 1 & 2 & 3 & 4 & 5 & 6 & 7 & 8 & 9 & 10 \\
\hline (RI) & 0 & 0 & 0.58 & 0.9 & 1.12 & 1.24 & 1.32 & 1.41 & 1.45 & 1.49 \\
\hline \hline
\end{tabular}


The $1^{\text {st }}$ International Conference on Business and Management of Technology (IConBMT)

August 3rd 2019, Institut Teknologi Sepuluh Nopember, Surabaya, Indonesia

TABLE 3.

PREVIOUS RESEARCH

\begin{tabular}{|c|c|c|c|c|}
\hline No. & Researcher & Title & Method & Results \\
\hline 1 & $\begin{array}{l}\text { Deng et al } \\
\text { (2014) }\end{array}$ & $\begin{array}{l}\text { Supplier Selection Using AHP } \\
\text { Methodology }\end{array}$ & D-AHP & $\begin{array}{l}\text { Number D is a new representation that is considered appropriate } \\
\text { and effective from uncertain information. The D-AHP method can } \\
\text { solve the problem of choosing suppliers on classic issues }\end{array}$ \\
\hline 2 & $\begin{array}{l}\text { Alikhani, } \\
\text { Torabi and } \\
\text { Altay, (2019) }\end{array}$ & $\begin{array}{l}\text { Strategic Supplier Selection Under } \\
\text { Sustainability and Risk Criteria }\end{array}$ & $\begin{array}{l}\text { Fuzzy and } \\
\text { DEA model }\end{array}$ & $\begin{array}{l}\text { The real case shows the efficiency of the application of the } \\
\text { proposed framework The results show that consideration of } \\
\text { sustainability criteria and risk factors is the right decision }\end{array}$ \\
\hline 3 & $\begin{array}{l}\text { Xiao, Chen and } \\
\mathrm{Li},(2012\end{array}$ & $\begin{array}{l}\text { An Integrated Fuzzy Cognitive MAP } \\
\text { (FCM) and Fuzzy Soft Set for Supplier } \\
\text { Selection Problem Based on Risk } \\
\text { Evaluation Hierarchy Process (AHP) }\end{array}$ & $\begin{array}{l}\text { FCM and } \\
\text { AHP }\end{array}$ & $\begin{array}{l}\text { The method does not only consider the adverse effects of the } \\
\text { criteria, but also considers the uncertainty of the decision. At the } \\
\text { end of this study, the selection of suppliers considers risk factors to } \\
\text { show the level of effectiveness. }\end{array}$ \\
\hline 5 & $\begin{array}{l}\text { Jumandono and } \\
\text { Singgih (2019) }\end{array}$ & $\begin{array}{l}\text { Selection of Shipping Container } \\
\text { Vendors Used Analytical Hierarchy } \\
\text { Process (AHP) Method }\end{array}$ & $\begin{array}{l}\text { FGD and } \\
\text { AHP }\end{array}$ & $\begin{array}{l}\text { Selection of shipping container vendors can be completed by a } \\
\text { combination of FGD and AHP methods. FGD method for } \\
\text { formulating assessment criteria and AHP methods to determine the } \\
\text { end of vendor selection. }\end{array}$ \\
\hline
\end{tabular}

\section{METHODOLOGY}

This study uses a combination of Focus Group Discussion (FGD) and Analytical Hierarchy Process (AHP) methods. The diagram in Figure 2 is the research design.

This research uses the FGD method and Analytical Hierarchy Process (AHP) method. The FGD method is a method used to find answers to each problem through expert forums or discussion groups. This method will produce relevant criteria. This FGD method will be combined with the AHP method which has a good structure. This is evidenced by the matrices produced until a consistency test. AHP method can solve problems that have multi-criteria up to sub-criteria.

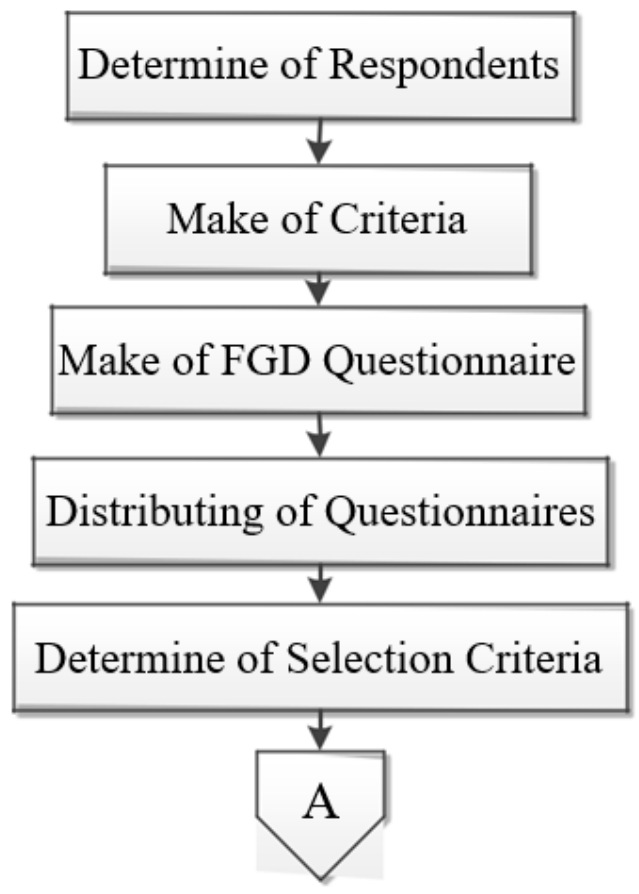

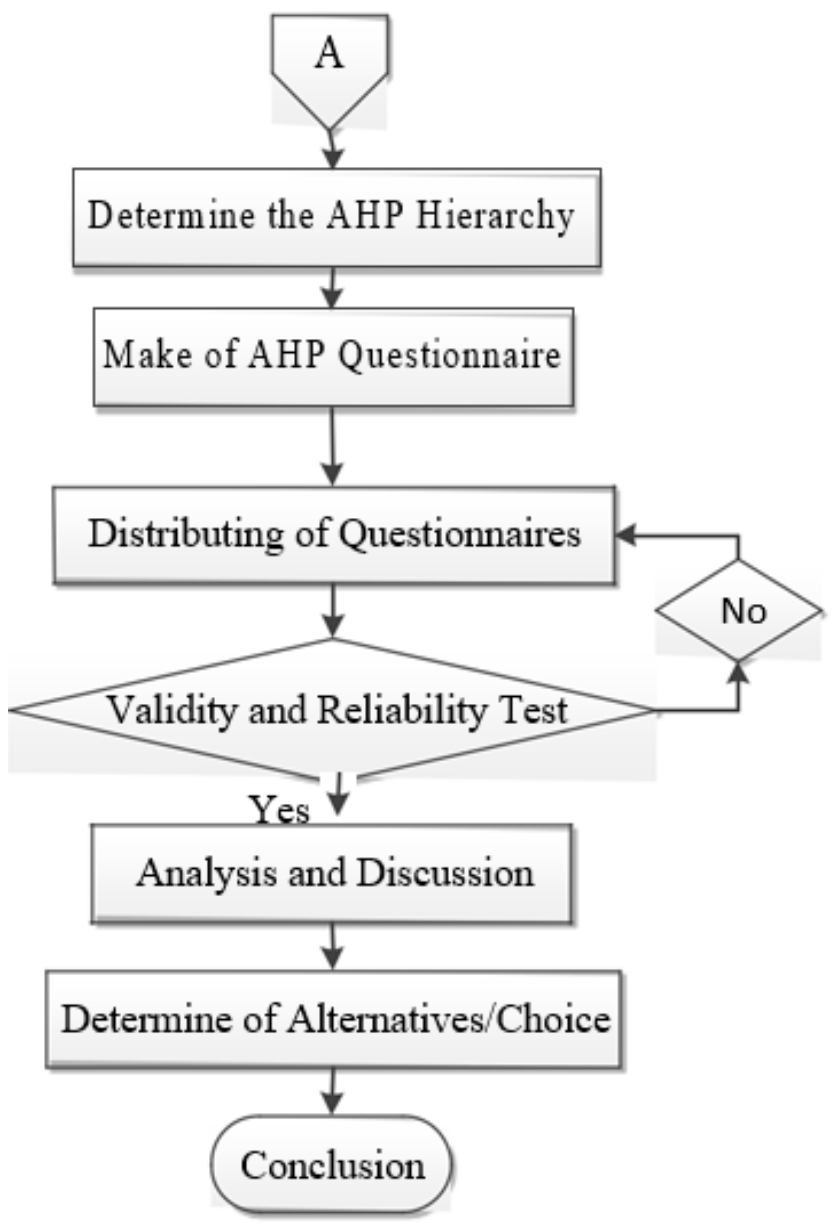

Figure 2. Research Flow Diagram.

\section{RESUlt AND DisCUSSION}

\section{A. FGD Method}

The FGD method was conducted to bring together the opinions of experts. Opinions processed using the FGD method are to determine the criteria used in the assessment. This analysis is also carried out to eliminate criteria that 
should not be included in the assessment. In addition to the selection criteria or the main criteria, there are sub-criteria that are also assessed in this study.

TABLE 4.

FINALLY RESULTS ON FGD METHOD

\begin{tabular}{cl}
\hline \multicolumn{1}{c}{ FINALLY RESULTS ON FGD METHOD } \\
\hline \hline No & \multicolumn{1}{c}{ Criteria } \\
\hline 2 & Cost \\
3 & Lime \\
4 & Quality \\
5 & Company Profile \\
6 & Contract Exploitation \\
7 & Standard and Environmental Certification \\
8 & Order Fullfilment \\
9 & Bankruptcy \\
10 & Capabilities Technology Administration \\
1.1 & Transportation Cost \\
1.2 & Cost Negotiation \\
1.3 & Promo \\
2.1 & Ontime Delivery \\
2.2 & Speed of Delivery Time \\
3.1 & Trust \\
3.2 & Information Conformity \\
3.3 & Comitment \\
4.1 & Container Quality \\
4.2 & Stability in Container Quality \\
5.1 & Facility \\
5.2 & Financial Status \\
5.3 & Transaction History \\
10.1 & Ease of Administration \\
10.2 & Technology Inovation \\
10.3 & Time of Administration Process \\
\hline \hline & \\
\hline
\end{tabular}

The reason for the reduction in the Administrative Technology Ability criteria according to experts is that so far the company has not experienced problems from managing documents with any vendor. Reduction of Promo sub criteria on Cost criteria according to experts in the technical field of the vendor party never gives a promo. Reduction of Container Quality Stability criteria for several reasons experts does not need to be included because it is sufficiently represented by Quality. Finally, the sub-criteria of Transaction History is discharged. The Sub Criteria do not affect the research because in determining the vendor the company has never seen transaction history. Discussions and iterations have reached the final stage.

\section{B. AHP Method}

The first step in the AHP method stage is to determine the hierarchy of problems. This hierarchy is the first reference in determining the next step. The hierarchy arrangement consists of Objectives, Criteria, Sub Criteria, and Alternatives or Options. The following is a hierarchical arrangement in which is assisted by expert choice v11 software. Entering data from each expert is adjusted to the questionnaire that has been filled. After everything is filled up to the vendor, it is united in the final concept. Selected vendors are vendor $\mathrm{B}$ has the highest priority with value $(36.8 \%)$, then followed by vendor A ranked second with $(33.9 \%)$, and the last is vendor $\mathrm{C}$ with value $(29.3 \%)$. Criteria Assessment also provides data systematically with the first rank in a row until the last rank is Quality criteria with a value $(22.6 \%)$, Cost criteria with a value $(22.4 \%)$, Time criteria with a value $(18.3 \%)$, Bankruptcy criteria with a value $(7.6 \%)$, Long-term Cooperation criteria with a value $(6.9 \%)$, criteria for Order Fulfillment with a value $(6.1 \%)$, criteria for a Company Profile with a value $(5.6 \%)$, Standard and Environmental Certification criteria with a value $(5.4 \%)$, and finally the Exploitation Contract criteria with a value $(5.1 \%)$.

\section{CONCLUSION}

1. Criteria and sub criteria used are derived from previous research, there are [8]-[17]. The research includes vendor selection and supplier selection.

2. Selection of criteria using the Focus Group Discussion (FGD) method is the right method to unite the opinions of experts. The FGD method can provide definite information on what experts have thought before starting the assessment.

3. The criteria that have been reducing the criteria for Ease of Administrative Technology. Sub-criteria that have been reducing are Promo (Cost), Stability of Container Quality (Container Quality), and Transaction History (Company Profile).

4. Selected vendors are vendor $\mathrm{B}$ has the highest priority with value $(36.8 \%)$, then followed by vendor A ranked second with $(33.9 \%)$, and the last is vendor $\mathrm{C}$ with value (29.3\%). Criteria Assessment also provides data systematically with the first rank in a row until the last rank is Quality criteria with a value $(22.6 \%)$, Cost criteria with a value $(22.4 \%)$, Time criteria with a value $(18.3 \%)$, Bankruptcy criteria with a value (7.6\%), Long-term Cooperation criteria with a value $(6.9 \%)$, criteria for Order Fulfillment with a value $(6.1 \%)$, criteria for a Company Profile with a value (5.6\%), Standard and Environmental Certification criteria with a value $(5.4 \%)$, and finally the Exploitation Contract criteria with a value (5.1\%).

\section{REFERENCES}

[1] M. Shahvali and K. Zarafshani, "Using PRA techniques as metacognitive strategies to develop indigenous knowledge - a case study," Int. Soc. Sci. J., vol. 54, no. 173, pp. 413-419, Sep. 2002.

[2] P. S. Kidd and M. B. Parshall, "Getting the focus and the group: Enhancing analytical rigor in focus group research," Qual. Health Res., vol. 10, no. 3, pp. 293-308, May 2000.

[3] R. Kraaijvanger, M. Sonneveld, C. Almekinders, and T. Veldkamp, "Comparison of methods to identify crop productivity constraints in developing countries. A review," 
The $1^{\text {st }}$ International Conference on Business and Management of Technology (IConBMT)

August 3rd 2019, Institut Teknologi Sepuluh Nopember, Surabaya, Indonesia

Agron. Sustain. Dev., vol. 35, no. 2, pp. 625-637, Apr. 2015.

[4] L. L. Trenkner and C. L. Achterberg, "Use of focus groups in evaluating nutrition education materials.," J. Am. Diet. Assoc., vol. 91, no. 12, pp. 1577-81, Dec. 1991

[5] T. L. Saaty, Decision Making for Leaders: The Analytical Hierarchy Process for Decisions in a Complex World. Pittsburgh, Pennsylvania: RWS Publications, 1999.

[6] U. Ciptomulyono, "Fuzzy goal programming approach for deriving priority weights in the Analytical Hierarchy Process (AHP) method," J. Appl. Sci. Res., vol. 4, no. 2, pp. 171-177, 2008.

[7] D. Darmapala and M. L. Singgih, "Risk Based Maintenance (RBM) untuk natural gas pipeline pada perusahaan $\mathrm{X}$ dengan menggunakan metode kombinasi AHP-index model," in Prosiding Seminar Nasional Manajemen Teknologi XV, 2012, p. A1.1-A1.8.

[8] R. Alikhani, S. A. Torabi, and N. Altay, "Strategic supplier selection under sustainability and risk criteria," Int. J. Prod. Econ., vol. 208, pp. 69-82, Feb. 2019.

[9] A. H. Azadnia, M. Z. M. Saman, and K. Y. Wong, "Sustainable supplier selection and order lot-sizing: an integrated multiobjective decision-making process," Int. J. Prod. Res., vol. 53, no. 2, pp. 383-408, Jan. 2015.

[10] C. Y. Chiou, C. W. Hsu, and W. Y. Hwang, "Comparative investigation on green supplier selection of the American, Japanese and Taiwanese Electronics Industry in China," in 2008 IEEE International Conference on Industrial Engineering and Engineering Management, 2008, pp. 1909-1914.
[11] R. M. Grisi, L. Guerra, and G. Naviglio, "Supplier Performance Evaluation for Green Supply Chain Management," in Business Performance Measurement and Management, Berlin, Heidelberg: Springer Berlin Heidelberg, 2010, pp. 149-163.

[12] R. J. Kuo, Y. C. Wang, and F. C. Tien, "Integration of artificial neural network and MADA methods for green supplier selection," J. Clean. Prod., vol. 18, no. 12, pp. 1161-1170, Aug. 2010.

[13] Z. Xiao, W. Chen, and L. Li, "An integrated FCM and fuzzy soft set for supplier selection problem based on risk evaluation," Appl. Math. Model., vol. 36, no. 4, pp. 1444-1454, Apr. 2012.

[14] R. Valverde and M. Talla, "Risk reduction of the supply chain through pooling losses in case of bankruptcy of suppliers using theblack-scholes-merton pricing model," in Some Recent Advances in Mathematics and Statistics, World Scientific, 2013, pp. $248-256$.

[15] A. H. I. Lee, H.-Y. Kang, C.-F. Hsu, and H.-C. Hung, "A green supplier selection model for high-tech industry," Expert Syst. Appl., vol. 36, no. 4, pp. 7917-7927, May 2009.

[16] K. H. Wathne and J. B. Heide, "Opportunism in interfirm relationships: Forms, outcomes, and solutions," J. Mark., vol. 64 , no. 4, pp. 36-51, 2000

[17] X. Deng, Y. Hu, Y. Deng, and S. Mahadevan, "Supplier selection using AHP methodology extended by D numbers," Expert Syst. Appl., vol. 41, no. 1, pp. 156-167, Jan. 2014. 